\title{
Population dynamics of Helicoverpa armigera in pearl millet
}

\author{
A. B. MAKWANA ${ }^{1}$, G. M. PARMAR ${ }^{2 *}$, ASHA C. DETROJA ${ }^{2}$ AND M.G. RATHWA ${ }^{1}$ \\ ${ }^{1}$ Department of Entomology, College of Agriculture, Junagadh Agriculture University, JUNAGADH (GUJARAT) INDIA \\ ${ }^{2}$ Millet Research Station (J.A.U.), JAMNAGAR (GUJARAT) INDIA
}

\section{ARITCLE INFO}

Received : 23.03 .2017

Revised : 21.08 .2017

Accepted : 03.09.2017

\section{KEY WORDS :}

Population dynamics, Pearl millet, Helicoverpa armigera

*Corresponding author:

\begin{abstract}
:
Population dynamics of Helicoverpa armigera in pearl millet was studied during Kharif 2015 at Instructional Farm, Junagadh Agricultural University, Junagadh. The study revealed that the pest incidence commenced from seventh week after sowing in variety GHB-558 and was found active from August to September in the crop. The pest population increased in the last week of August and reaching to a peak level of 1.56 larvae per ear head. Then it was decreased ( 0.82 larvae/ear head) during the first week of September and remained active steady upto second week of September. Among the different parameters, maximum temperature and mean bright sunshine hours showed positive correlation whereas minimum temperature, morning relative humidity showed negative correlation with population of this pest but did not reached at significant level. However, the correlation between the pest population and evening relative humidity was significant and negative. Rainfall exhibited a non-significant and negative correlation with the pest population.
\end{abstract}

How to view point the article : Makwana, A.B., Parmar, G.M., Detroja, Asha C. and Rathwa, M.G. (2017). Population dynamics of Helicoverpa armigera in pearl millet. Internat. J. Plant Protec., 10(2) : 339-343, DOI : 10.15740/HAS/IJPP/10.2/339-343. 